\section{EFEKTIFITAS EDUKASI KESEHATAN TERINTEGRASI PADA PASIEN PRE DAN POST OPERASI PANGGUL : LITERATURE REVIEW}

\author{
The Effectiveness of Integrated Health Education Among \\ Patient Undergo Pre and Post Hip Surgery: A Literature Review
}

\author{
Anas Khafid *1, Riri Maria2 \\ 1. Mahasiswa Magister Keperawatan, Faculty of Nursing, Universitas Indonesia \\ 2. Dosen, Department Medikal-Bedah, Fakultas Ilmu Keperawatan, Universitas Indonesia
}

\section{Riwayat artikel}

Diajukan: 13 Februari 2020

Diterima: 28 Maret 2020

\section{Penulis Korespondensi:}

- Anas Khafid S

- Magister Keperawatan, Faculty of Nursing, Universitas Indonesia

- anaskhafid83@gmail.co $\mathrm{m}$

\section{Kata Kunci: \\ Arthroplasty, Edukasi kesehatan, Operasi panggul, Pendidikan kesehatan,}

Pendahuluan : Fraktur tulang panggul merupakan masalah utama yang terus berkembang secara signifikan pada lansia di seluruh dunia. Arthroplasti panggul merupakan salah satu prosedur yang direkomendasikan ketika pengobatan dan terapi fisik tidak lagi efektif. Intervensi edukasi kesehatan umum dilakukan oleh petugas kesehatan akan terapi metode yang dilakukan kurang efektif dan akan berdampak jangka pendek dan panjang pada aspek fisik maupun psikologis pasien Tujuan tinjauan literature ini mengeksplorasi efektifitas pendidikan kesehatan pada pasien dengan pre dan post operasi tulang panggul. Metode : Pencarian literature dilakukan pada lima database terbesar yaitu Pubmed, Google Scholar, CINAHL, Medline dan PsycINFO dengan menggunakan kata kunci "Health Education", "Patient Education", "Educational", "Hip Surgery", "Hip Arthroplasty" dan "Health Education and Hip Arthroplasty". Pencarian kata kunci juga dikombinasikan agar literatur yang didapatkan lebih spesifik. Hasil : Dari 20 artikel yang ditemukan dalam pencarian lima artikel dianalisis lebih lanjut dan ditemukan tujuh efek edukasi kesehatan pada pengetahuan dan perilaku, nyeri, Activity Daily Living (ADL), kualitas hidup, fungsi, kesembuhan panggul dan lama rawat, self-efficacy dan depresi. Diskusi: Edukasi kesehatan memerlukan

penggunaan media, durasi yang efektif dan metode terintegrasi yang tepat sehingga akan memengaruhi proses pemulihan dan rehabilitasi. Kelima studi menunjukkan keefektifan edukasi pada pasien operasi panggul dan setiap studi memiliki hasil yang saling menguatkan satu dan lainnya.

\section{Abstract}

Introduction: Hip fracture is a major problem in the elderly throughout the world. Hip arthroplasty is a procedure when treatment and physical therapy are no longer effective. Health education delivers by health care professionals who less will have an impact on the short and long term both physically and mentally. The purpose of this literature review is to explore the effectiveness of health education among patients who undergo pre and post hip surgery. Method: Literature research conducted on the five largest databases consist of Pubmed, Google Scholar, CINAHL, Medline and PsycINFO using medical subject headings "Health Education",

"Patient Education", "Educational", "Hip Surgery", "Hip Arthroplasty" and "Health Education and Hip Arthroplasty ". The combination of keywords searches to find more specific literature. Results: We found 20 articles and five articles are analyzed further. Seven effects of health education impacted knowledge and behavior, pain, Activity Daily Living (ADL), quality of life, function, hip healing and length of stay, self-efficacy and depression. Discussion: Health education requires the appropriate media, duration and integrated methods; therefore, it will increase the recovery and rehabilitation process. Five studies showed the effectiveness of education in patients with hip surgery and the result of each study reinforcing each other. 


\section{Pendahuluan}

Fraktur tulang panggul merupakan masalah utama yang terus berkembang di seluruh dunia secara signifikan dari kasus 1,7 juta/tahun pada tahun 1990, diperkirakan meningkat 4 kali lipat dan mencapai 6,3 juta/tahun pada tahun 2050 (Friedman \& Mendelson, 2014). Penyebab utamanya adalah osteoarthritis yang merupakan penyakit yang berkaitan erat dengan proses degenerasi pada lansia yang populasinya di tahun 2020 akan lebih banyak dibandingkan balita (WHO, 2018). Hal tersebut akan berdapak pada peningkatan sosial ekonomi dan potensial menjadi beban kesehatan di masa mendatang. Di Jerman, kasus patah tulang panggul mencapai 130.000 dengan 40 $\%$ diagnosa terbanyak adalah fraktur leher femur (Saul, Riekenberg, Ammon, Hoffmann, \& Sehmisch, 2019).

Pilihan operasi yang sering dipertimbangkan dalam mengelola masalah sendi panggul adalah reduksi, fiksasi interna, hip arthoplasty (Zairin, 2016). Arthoplasti pinggul merupakan intervensi yang efektif dan efisien pada orang dewasa dan lansia yang di rekomendasikan ketika pengobatan dan terapi fisik memberikan efek yang maksimal, contohnya pada kehilangan gerakan sendi (Barnsley, Barnsley, \& Page, 2015; Luz Rodríguez Acelas et al., 2019).

Operasi panggul dapat meningkatkan kualitas hidup pasien karena memiliki efek dapat meningkatakan kemapuan fungsional dan mengurangi nyeri (Luz Rodríguez Acelas et al., 2019). Akan tetapi proses pemulihan membutuhkan waktu yang lama dengan berbagai efek dan komplikasi pada kesehatan baik fisik maupun psikolgis. Kebutuhan akan edukasi kesehatan sangat penting terutama dalam manajemen nyeri pasca operasi meliputi informasi mengenai fungsi obat, cara mengkonsumsi obat dan efek sampingnya (Kennedy et al., (2017). Personal edukator dibutuhkan untuk meningkatkan keterbukaan pasien dalam bertanya secara langsung mengenai penyakitnya karena hal ini terbukti dapat menurunkan lama rawat di rumah sakit (Yoon et al, 2010)

Edukasi kesehatan yang efektif berfokus pada usaha dalam perubahan perilaku kesehatan, berdasarkan pada teori serta penelitian, dan model pembelajaran maupun materi yang terintegrasi (CDC, 2019). Berbagai penelitian mendeskripsikan bahwa edukasi kesehatan pada proses pre dan post operasi membutuhkan persiapan yang terencana karena fase recovery dan rehabilitasi akan mempengaruhi fisik dan psikologi pasien dalam jangka pendek dan panjang (McDonald, Page, Beringer, Wasiak, Sprowson, 2014). Model edukasi kesehatan bersifat dinamis dan terdiri dari bermacammacam strategi dalam melibatkan tim petugas kesehatan, penggunaan metode konvensional maupun pemanfaatan teknologi dan media alat bantu. Berdasarkan penjelasan tersebut dibutuhkan tinjauan literature mengeksplorasi efek pendidikan kesehatan pada pasien dengan pre dan post operasi tulang panggul

\section{Metodologi}

Dalam studi ini yang pencarian literature berfokus pada peran edukasi pelayanan kesehatan pada pasien pre dan post operasi pinggul. Lima database terbesar dalam dunia kesehatan digunakan dalam proses ini yang meliputi Pubmed, Google Scholar, CINAHL, Medline dan PsycINFO dengan menggunakan kata kunci "Health Education", "Patient Education", "Educational", "Hip Surgery", "Hip Arthroplasty" dan "Health Education and Hip Arthroplasty”. Pencarian kata kunci juga dikombinasikan agar literatur yang didapatkan lebih spesifik. Kriteria inklusi meliputi: 1) Studi yang termasuk dalam tinjauan literature ini terdiri dari randomised control trial, cohort study, dan kualitatif study. n 2019, 2) Publikasi artikel dalam sepulu tahun terakhir 2010-2020 3) Artikel menggunakan Bahasa Inggris dan memiliki full text. Artikel yang tidak termasuk kedalam 
kriteria inklusi di keluarkan. Proses pencarian literature dideskripsikan dalam Gambar 1

Seleksi artikel yang dilakukan terdiri dari semua judul dan abstrak yang muncul dalam pencarian dipertimbangkan secara independen oleh penulis untuk kelayakannya sesuai dengan kriteria inklusi dan full text diperoleh. Artikel lengkapnya kemudian dinilai kelayakannya lagi sesuai dengan kriteria yang diharpkan penulis. Data yang didapatkan dilakukan review secara detail, data di seleksi mengenai jumlah sampel penelitian, jenis dan metode edukasi, dan hasil edukasi kesehatan.

\section{Hasil}

Dari 20 artikel yang diemukan dalam pencarian ada lima artikel yang diambil untuk di lakukan review. Dua artikel ( Huang, Sung, Wang, Wang 2017 dan Shen et al., 2017) adalah penelitian yang menggunakan metode Randomized Controlled Trial (RCT), dua artikel menggunakan metode quasi eksperimental (Gurcayir, Karabulut, 2017 dan Yoon et al., 2010) dan satu artikel adalah penelitian cohort (Reilly, Mohamed, Foy, Sheehan, 2018). Berdasarkan lima artikel tersebut didapatkan tujuh efek edukasi kesehatan pada pasien pre dan post operasi panggul yaitu 1) Pengetahuan dan perilaku, 2) Nyeri, 3) Activity Daily Living (ADL), 4) Kualitas hidup, 5) Fungsi, kesembuhan panggul dan lama rawat 6) Self-efficacy dan 7) Depresi. Analisis artikel dijelaskan pada Tabel 1.

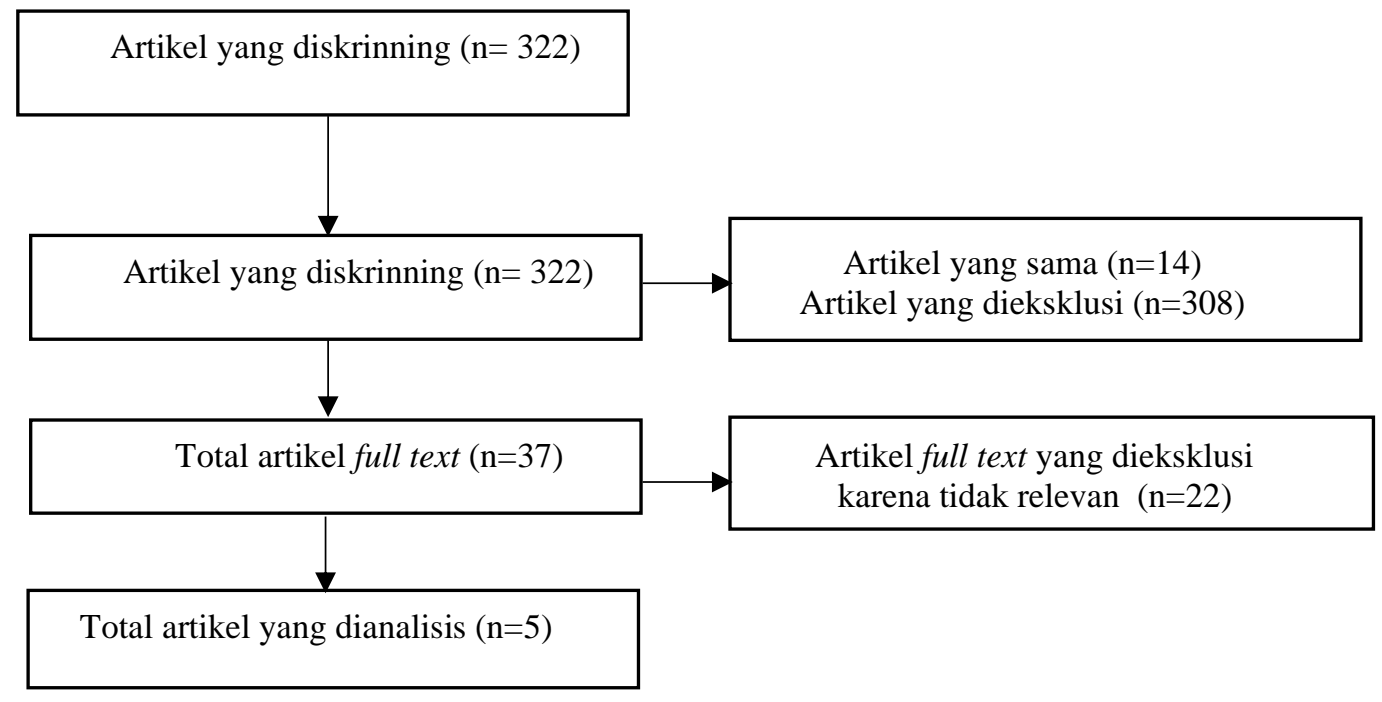

Gambar 1. Bagan Alur Review

\section{Pembahasan}

\section{Pengetahuan dan perilaku}

Dua artikel mendeskripsikan efek edukasi kesehatan terhadap pengetahuan dan perilaku (Huang, Sung, Wang, Wang, 2017 dan Reilly, Mohamed, Foy, 2018). Terdapat perbedaan pengetahuan dan perilaku terhadap perawatan diri secara mandiri. Dalam intervensi tersebut responden diberikan kesempatan untuk mengkaji kebutuhan, mengindetifikasi kemampuan dan dukungan yang tersedia dan mungkin dapat diterima setelah dilakukan operasi panggul.
Melalui metode ini responden dapat mempersiapkan lebih dini dan petugas kesehatan dapat memberikan masukan secara spesifik berdasarkan hasil tiap individu. Edukasi kesehatan diberikan secara terstrukur dan melibatkan semua tim kesehatan yang akan terlibat langsung dalam pre- post operasi. Topik materi tidak terbatas mengenai pengetahuan mengenai prosedur operasi, perawatan di rumah sakit atau kesadaran akan komplikasi tetapi responden menunjukkan peningkatan pengetahuan dan perilaku mandiri dalam kepatuhan obat, 
pemeriksaan rutin, rehabulitasi, aktvitas fisik dan manajemen nyeri. 
Tabel 1. Ringkasan hasil analisis artikel

\begin{tabular}{|c|c|c|c|c|c|}
\hline No & Judul dan Penulis & Metode & Sampel & Hasil & Kesimpulan \\
\hline 1 & $\begin{array}{l}\text { The Effects of the } \\
\text { Empowerment Education } \\
\text { Program in Older Adults } \\
\text { with Total Hip } \\
\text { Replacement Surgery } \\
\text { (Huang, T. T., Sung, C. } \\
\text { C., Wang, W. S., \& Wang, } \\
\text { B. H, 2017) }\end{array}$ & $\begin{array}{l}\text { a. Design : Randomized } \\
\text { Controlled Trial (RCT) } \\
\text { b. Instrument: } \\
\text { 1. Total Hip Replacement } \\
\text { (THR) Self-Efficacy Scale } \\
\text { CVI }=0.91 \\
\text { Test-retest (r) }=0.81 \\
\text { Cronbach's } \alpha=0.74 \\
\text { 2. Total Hip Replacement } \\
\text { (THR) Self-Care } \\
\text { Competence Scale } \\
\text { Test-retest (r) }=0.83 \\
\text { Cronbach's } \alpha=0.72 \\
\text { 3. Barthel Scale (1995) : } \\
\text { Crobach's } \alpha=0.86 \\
\text { 4. Tinetti Mobility Scale (196) } \\
\text { Cronbach's } \alpha=0.88 \\
\text { 5. Geriatric Depression Scale } \\
\text { (GDS) Cronbach's } \alpha=0.89 \\
\text { 6. SF-36 Health-related } \\
\text { Quality of Life (HRQOL) } \\
\text { Cronbach's } \alpha=0.77-0.83\end{array}$ & $\begin{array}{l}\text { Teknik randomisasi dilakukan dengan } \\
\text { computer-based untuk membagi } \\
\text { responden dalam dua grup (intervensi } \\
\text { dan kontrol). Asisten peneliti tidak } \\
\text { mengetahui status tiap responden. Data } \\
\text { diambil pada September 2013-Mei } 2014 \\
\text { dan dilakukan pengukuran selama tiga } \\
\text { kali yaitu saat responden keluar dari RS, } \\
\text { satu bulan dan tiga bulan setelah keluar } \\
\text { dari RS. } \\
\text { a. Intervensi Education empowerment } \\
\text { Group (n=54) : Program yang } \\
\text { dilakukan selama 5x selama } 12 \\
\text { minggu dan berfokus pada eksplorasi } \\
\text { kemampuan responden dalam } \\
\text { mengungkapkan keinginan dan } \\
\text { kemampuannya pasca THR. follow- } \\
\text { up dilakukan pada minggu ke } 2,6 \text {, dan } \\
10 \text { setelah responden pulang dari } \\
\text { rumah sakit } \\
\text { b. Kontrol Group (n=54) : Responden } \\
\text { mendapatkan pendidikan kesehatan } \\
\text { umum yang sudah dilaksanakan } \\
\text { sebelumnya (konseling dan pemberian } \\
\text { brosur) }\end{array}$ & $\begin{array}{l}\text { 1. Rata-rata usia responden 66.05 (SD } \\
\pm 9.46 \text { ) dan mayoritas adalah laki-laki, } \\
\text { menikah, tinggal bersama keluarga, } \\
\text { obesitas dan memiliki penyakit kronis } \\
\text { 2. Perbedaan self-efficacy, self- } \\
\text { competence, pengetahuan dan perilaku } \\
\text { yang siginifikan secara statistik pada } \\
\text { grup intevensi dan kontrol (p<0.001) } \\
\text { 3. Peningkatan activity daily living (ADL) } \\
\text { terjadi pada kedua grup tetapi pada } \\
\text { komponen cara berjalan grup intervensi } \\
\text { menunjukkan skor yang lebih tinggi } \\
\text { dibandingkan dengan grup kontrol } \\
\text { (p<0.05) } \\
\text { 4. Penurunan gejala depresi yang } \\
\text { signifikan secara statistik pada grup } \\
\text { intervensi dibandingkan dengan grup } \\
\text { kontrol (p<0.001) } \\
\text { 5. Terjadi peningkatan kualitas hidup pada } \\
\text { grup intervensi dan kontrol (p<0.001) }\end{array}$ & $\begin{array}{l}\text { 1. Program edukasi kesehatan pada } \\
\text { pasien THR dapat dilakukan } \\
\text { pada fase pre-operasi, } \\
\text { hospitalisasi dan follow-up } \\
\text { setelah pasien pulang. } \\
\text { 2. Fokus utama pemberdayaan } \\
\text { pendidikan kesehatan adalah } \\
\text { menciptakan kesadaran } \\
\text { responden mengenai kebutuhan, } \\
\text { kemampuan dan dukungan yang } \\
\text { dapat didapatkan terhadap } \\
\text { perawatan diri pasca } \\
\text { dilakukannya THR. }\end{array}$ \\
\hline 2 & $\begin{array}{l}\text { The Effects of the } \\
\text { Training Provided to } \\
\text { Patients who are } \\
\text { scheduled for Hip } \\
\text { Prosthesis Surgery on the } \\
\text { Level of Postoperative } \\
\text { Comfort and Daily } \\
\text { (Gurcayir, D., \& } \\
\text { Karabulut, N, 2017) }\end{array}$ & $\begin{array}{l}\text { a. Design : Quasi Experimen } \\
\text { b. Instrument : } \\
\text { 1. Barthel Index (1965) } \\
\text { Cronbach's Alpha = } 0.88 \\
\text { 2. The Oxford Hip Score } \\
\text { Cronbach's Alpha =0.89 } \\
\text { 3. The Perianesthesia } \\
\text { Comfort Questionnaire } \\
\text { Cronbach's Alpha =0.83 } \\
\text { 4. The General Comfort }\end{array}$ & $\begin{array}{l}\text { 1. Responden dibagi menjadi dua grup } \\
\text { (intervensi dan kontrol) dengan total } \\
30 \text { responden di setiap grup. } \\
\text { 2. Pada grup intervensi, booklet } \\
\text { diberikan kepada responden dan } \\
\text { berisi materi edukasi mengenai } \\
\text { kondisi yang akan terjadi pada } \\
\text { pasien sebelum, selama dan sesudah } \\
\text { operasi panggul. } \\
\text { 3. Booklet berisi informasi yang }\end{array}$ & $\begin{array}{l}\text { 1. Rata-rata usia responden } 60.6 \text { (SD } \\
\pm 6.92 \text { ) dan sebagian besar responden di } \\
\text { kelompok kontrol adalah perempuan } \\
\text { sedangkan di kelompok intervensi } \\
\text { adalah laki-laki dan mengalami fraktur } \\
\text { 2. Terdapat perbedaan rata-rata skor } \\
\text { activity daily living (ADL) sebulan } \\
\text { pasca operasi pada grup intevensi dan } \\
\text { kontrol yang terbukti signifikan secara } \\
\text { statistik }(\mathrm{p}<0.000)\end{array}$ & $\begin{array}{l}\text { Perawat dapat memberikan edukasi } \\
\text { kesehatan yang efektif dan } \\
\text { terencana dengan melibatkan } \\
\text { sumber tertulis dan materi visual } \\
\text { yang interaktif. }\end{array}$ \\
\hline
\end{tabular}




\begin{tabular}{|c|c|c|c|c|c|}
\hline No & Judul dan Penulis & Metode & Sampel & Hasil & Kesimpulan \\
\hline & & $\begin{array}{l}\text { Questionnaire } \\
\text { Cronbach's Alpha }=0.85\end{array}$ & $\begin{array}{l}\text { lengkap dan materi di dalamnya } \\
\text { akan disampaikan atau dipraktikkan } \\
\text { pada pre dan post operasi. } \\
\text { 4. Data diambil dalam empat kali } \\
\text { pengukuran pada bulan Juli- } \\
\text { Desember } 2010\end{array}$ & $\begin{array}{l}\text { 3. Terdapat perbedaan rata-rata skor status } \\
\text { kesembuhan panggul antara grup } \\
\text { intevensi dan kontrol yang terbukti } \\
\text { signifikan secara statistik ( }<<0.000) \\
\text { 4. Terdapat perbedaan rata-rata skor } \\
\text { kenyamanan } 24 \text { jam pascara operasi dan } \\
\text { pada saat responden pulang dari RS } \\
\text { antara grup intevensi vs kontrol dan } \\
\text { terbukti signifikan secara statistik (p < } \\
0.000)\end{array}$ & \\
\hline 3 & $\begin{array}{l}\text { Educational impact of } \\
\text { joint replacement school } \\
\text { for patients undergoing } \\
\text { total hip and knee } \\
\text { arthroplasty: ra } \\
\text { prospective cohort study } \\
\text { (Reilly, M. O., Mohamed, } \\
\text { K., Foy, D., \& Sheehan, E. } \\
\text { 2018) }\end{array}$ & $\begin{array}{l}\text { a. Design : Prospective } \\
\text { Cohort } \\
\text { b. Instrument : Pre Joint } \\
\text { School Questionnaire }\end{array}$ & $\begin{array}{l}\text { 1. Total } 51 \text { responden pada } 4 \text { sekolah } \\
\text { sendi yang berbeda mengikuti sesi } \\
\text { pendidikan kesehatan sebelum } \\
\text { dilakukan tindakan operasi } \\
\text { 2. Sesi dilakukan selama } 75-90 \text { menit } \\
\text { dengan mengkombinasikan } \\
\text { penyampaian materi dan diskusi } \\
\text { secara verbal, audio, visual dan } \\
\text { model-based teaching } \\
\text { menggunakan video, presentasi dan } \\
\text { demonstrasi dari berbagai petugas } \\
\text { kesehatan (perawat, dokter anestesi, } \\
\text { dokter bedah, fisioterapi, dan } \\
\text { okupasi) } \\
\text { 3. Responden diberikan paket modul } \\
\text { yang berisi semua informasi } \\
\text { mengenai operasi panggul }\end{array}$ & $\begin{array}{l}\text { 1. Rata-rata usia responden } 64.5 \text { (SD } \\
\pm 6.92 \text { ) dan sebagian besar adalah } \\
\text { perempuan } \\
\text { 2. Terdapat perbedaan skor sebelum dan } \\
\text { sesudah mengikuti sekolah sendi yang } \\
\text { terbukti signifikan secara statistik (p < } \\
\text { 0.001) pada aspek kesadaran akan } \\
\text { komplikasi operasi, kebutuhan pada saat } \\
\text { pendaftaran di rumah sakit, lama rawat, } \\
\text { pengetahuan mengenai prosedur } \\
\text { operasi, dan komplikasi pasca-operasi } \\
\text { akibat merokok } \\
\text { 3. Terdapat perbedaan skor pengetahuan } \\
\text { sebelum dan sesudah mengikuti sekolah } \\
\text { sendi yang terbukti signifikan secara } \\
\text { statistik (p<0.001) }\end{array}$ & $\begin{array}{l}\text { 1. Edukasi pada pre-operasi adalah } \\
\text { waktu yang sangat penting dan } \\
\text { efektif dalam memberikan } \\
\text { edukasi kesehatan kepada pasien } \\
\text { karena meningkatkan tingkat } \\
\text { kepercayaan diri, kepuasan dan } \\
\text { menurunkan kecemasan. } \\
\text { 2. Sekolah sendi merancang } \\
\text { pendidikan kesehatan dengan } \\
\text { melibatkan semua petugas } \\
\text { kesehatan sehingga informasi } \\
\text { dapat tersampaikan secara jelas } \\
\text { dan terstruktur }\end{array}$ \\
\hline 4 & $\begin{array}{l}\text { Patient Education } \\
\text { Before Hip or } \\
\text { Knee Arthroplasty } \\
\text { Lowers Length of Stay } \\
\text { (Yoon, R. S., Nellans, } \\
\text { K. W., Geller, J. A., } \\
\text { Kim, A. D., Jacobs, M. } \\
\text { R., \& Macaulay, W, } \\
\text { 2010). }\end{array}$ & $\begin{array}{l}\text { a. Design : Quasi } \\
\text { Experiment. Pengambilan } \\
\text { data dilakukan pada bulan } \\
\text { April 2006-Mei } 2007 \\
\text { b. Instrument : Length of } \\
\text { Stay (LOS) }\end{array}$ & $\begin{array}{l}\text { 1. Responden yang bersedia } \\
\text { mengikuti edukasi kesehatan } \\
\text { (n=163) yang dilakukan melalui } \\
\text { tatap muka langsung atau telepon } \\
\text { tiga minggu sebelum dilakukan } \\
\text { operasi panggul. } \\
\text { 2. Responden yang tidak bersedia } \\
\text { mengikuti edukasi kesehatan } \\
(n=89)\end{array}$ & $\begin{array}{l}\text { 1. Rata-rata usia responden } 66.3 \\
\text { (SD } \pm 11.7) \text { dan sebagian besar adalah } \\
\text { laki-laki } \\
\text { 2. Tidak ada perbedaan yang signifikan } \\
\text { secara statistik antara kelompok } \\
\text { intervensi dan kelompok kontrol } \\
\text { 3. Terdapat perbedaan lama rawat yang } \\
\text { lebih pendek 1 hari antara kelompok } \\
\text { intervensi dan kontrol dan terbukti } \\
\text { signifikan secara statistik (p < }\end{array}$ & 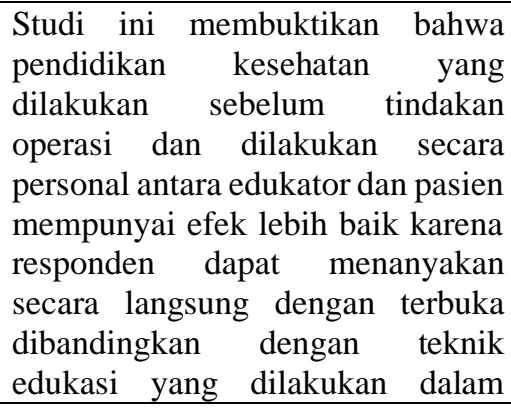 \\
\hline
\end{tabular}




\begin{tabular}{|c|c|c|c|c|c|}
\hline No & Judul dan Penulis & Metode & Sampel & Hasil & Kesimpulan \\
\hline & & & $\begin{array}{l}\text { 3. Edukasi kesehatan dilakukan } \\
\text { personal antara edukator dan } \\
\text { responden dengan menggunakan } \\
\text { modul booklet yang berisi topik } \\
\text { mengenai hal-hal yang akan } \\
\text { berkaitan dengan operasi panggul } \\
\text { (definisi, prosedur, fase recovery } \\
\text { dan rehabilitasi, nutrisi, instruksi } \\
\text { perawatan di rumah, dukungan } \\
\text { sosial dan spiritual dan topik } \\
\text { lainnya) }\end{array}$ & $0.0001)$ & kelompok besar. \\
\hline 5 & $\begin{array}{l}\text { Influence of mobile } \\
\text { education on joint } \\
\text { function and quality of } \\
\text { life in patients after total } \\
\text { hip arthroplasty } \\
\text { (Shen, W.-X., Wang, } \\
\text { Y.-X., Ning, Y.-Y., } \\
\text { Peng, J.-X., Wei, H.-Q., } \\
\text { Duan, K., ... Yuan, C.- } \\
\text { S, 2017) }\end{array}$ & $\begin{array}{l}\text { a. Design : Randomized } \\
\text { Controlled Trial (RCT) } \\
\text { b. Instrument } \\
\text { 1. Harris score } \\
\text { 2. Compliance functional } \\
\text { exercises } \\
\text { 3. Rehabilitation exercise } \\
\text { skills } \\
\text { 4. Nottingham } \\
\text { Profile (NHP) Health }\end{array}$ & $\begin{array}{l}\text { Teknik randomisasi menggunakan } \\
\text { penomoran tabel dilakukan untuk } \\
\text { membagi responden ke dalam grup } \\
\text { intevensi atau grup kontrol. Data } \\
\text { diambil selama dua kali yaitu pada saat } \\
\text { responden keluar dari RS dan } 12 \\
\text { minggu setelahnya. } \\
\text { a. Grup Intervensi (n=30): Pemberikan } \\
\text { materi edukasi berupa film animasi } \\
\text { 50 karakter kartun yang } \\
\text { menceritakan aktivitas kehidupan } \\
\text { sehari-hari di rumah setelah } \\
\text { menjalani Total Hip Arthroplasty } \\
\text { (THA). Materi diberikan saat pasien } \\
\text { masuk rumah sakit, sebelum dan } \\
\text { sesudah operasi dan 3x setelah } \\
\text { pulang dari rumah sakit. Perawat } \\
\text { membantu responden dalam } \\
\text { melakukan aktivitasnya berdasarkan } \\
\text { animasi film. } \\
\text { Grup kontrol (n=30): Responden } \\
\text { mendapatkan pendidikan kesehatan } \\
\text { yang rutin dilakukan di rumah sakit }\end{array}$ & $\begin{array}{l}\text { 1. Terdapat perbedaan statistik yang } \\
\text { signifikan ( } \mathrm{p}<0.0001 \text { ) pada fungsi } \\
\text { panggul, kepatuhan terhadap latihan } \\
\text { fisik dan kemampuan melakukan } \\
\text { rehabilitasi antara grup intervensi dan } \\
\text { kontrol } \\
\text { 2. Kualitas hidup antara grup intervensi } \\
\text { dan kontrol menunjukkan perbedaan } \\
\text { statistik yang signifikan (p< } 0.0001 \text { ) } \\
\text { dari enam aspek meliputi nyeri, energi, } \\
\text { kondisi tidur, aktivitas, respon emosi } \\
\text { dan sosial. }\end{array}$ & $\begin{array}{l}\text { Pendidikan kesehatan melalui } \\
\text { penggunaan animasi film } \\
\text { memberikan kemudahan akses dan } \\
\text { efisiensi bagi pasien dan tenaga } \\
\text { kesehatan dalam menjalani proses } \\
\text { rehabilitasi dalam waktu yang } \\
\text { lama. }\end{array}$ \\
\hline
\end{tabular}




\section{Nyeri}

Tujuan edukasi kesehatan salah satunya adalah peningkatan kemampuan responden dalam melakukan manajemen nyeri dan penurunan nyeri setelah dilakukan operasi panggul. Topik nyeri terdapat pada modul booklet yang disusun oleh Gurcayir, Karabulut (2017) yang membahas kontrol nyeri pada post operasi hari pertama. Pada artikel di dalam tinjauan literature ini nyeri termasuk ke dalam dimensi kualtas hidup (Shen et al., 2017) self-competence (Huang, Sung, Wang, 2017) dan kenyamanan pasca anestesi (Gurcayir, Karabulut, 2017).

Pendidikan kesehatan yang dilakukan sebelum operasi dapat membantu responden memiliki kontrol terhadap nyeri setelah efek anestesi hilang karena kemampuan dalam mengantisipasi efek nyeri. Edukasi kesehatan dalam bentuk animasi film yang menarik memberikan dampak emosi dan motivasi sehingga membantu responden menurunkan level nyeri dalam fase rehabilitasi setelah operasi

\section{Activity Daily Living (ADL)}

Kemampuan untuk melakukan aktivitas sehari-hari secara mandiri tanpa dibantu seperti mandi, buang air besar dan kecil, berjalan, berpakaian adalah tujuan responden bersedia melakukan operasi panggul. Melalui pendidikan kesehatan responden menjukkan peningkatan ADL pada komponen berjalan dan kemampuan menggunakan alat bantu gerak (Huang, Sung, Wang, Wang, 2017) dan.

Fase pemulihan pasca operasi adalah hal yang sangat penting untuk responden berlatih melakukan aktivitas mandiri sehingga peran petugas kesehatan sangat penting dalam hal ini. Peningkatan melakukan ADL seperti bangun dari tempat tidur, berjalan dan pergi ke toilet sebulan pasca operasi ditunjukkan pada kelompok yang mendapatkan edukasi kesehatan segera melakukan mobilisasi dini setelah operasi (Gurcayir, Karabulut (2017)

\section{Kualitas hidup}

Enam dimensi (Shen et al., 2017) dan delapan dimensi (Huang, Sung, Wang, Wang, 2017) kualitas hidup yang dibahas dalam artikel tersebut menunjukkan peningkatan signifikan bagi responden yang mendapatkan edukasi kesehatan. Dimensi fisik maupun mental meliputi nyeri, energi, kondisi tidur, aktivitas, respons emosi dan social menunjukkan peningkatan karena kemampuan positif dalam fase recovery setelah operasi. Kualitas hidup akan berubah dan dipengaruhi oleh usia (Zhang et al., 2016) Sebagian besar responden pada artikel rata-rata berusia antara 61-67 tahun sehingga diperlukan metode dan strategi khusus yang perlu diperhatikan dalam menyampaikan informasi kesehatan.

\section{Fungsi, kesembuhan panggul dan lama rawat}

Proses pemulihan panggul setelah operasi mempengaruhi lama rawat responden di rumah sakit. Edukasi kesehatan sebelum operasi memperpendek hospitalisasi sehingga proses tersebut dapat berlangsung lebih cepat. Perbedaan lama rawat yang lebih pendek satu hari ditunjukkan pada kelompok responden yang mendapatkan edukasi mengenai halhal yang harus diwaspai ketika operasi selesai dilakukan (Yoon et al., 2010). Selain itu kesembuhan panggul dan fungsi panggul yang lebih signifikan pada fase recovery dan rehabilitasi pasca pulang dari rumah sakit menunjukkan efektifitas edukasi kesehatan dalam periode tersebut (Gurcayir, Karabulut (2017; (Huang, Sung, Wang, Wang, 2017; Shen et al., 2017)

\section{Self-efficacy}

Responden yang mendapatkan
pemberdayaan edukasi $\begin{array}{r}\text { kesehatan } \\ \text { menunjukkan peningkatan self-efficacy }\end{array}$
yang bertahap selama tiga bulan dan satu
tahun setelah pulang dari rumah sakit
(Huang, Sung, Wang, Wang, 2017). Self-
efficacy adalah keyakinan yang dimiliki
oleh seseorang terhadap kemampuannya
untuk menghadapi permasalahan yang
dapat mempengaruhi kehidupannya


(Bandura, 1997). Keyakinan akan kemampuan responden dalam manajemen diri, lingkungan, melakukan pemeriksaan kesehatan secara rutin, melakukan latihan fisik dan mengkonsumsi obat-obatan adalah komponen dari self-efficacy yang dimiliki setelah dilakukannya operasi panggul

\section{Depresi}

Lansia memiliki resiko untuk mengalami depresi lebih tinggi dibandingkan populasi lainnya. Operasi panggul meningkatkan resiko depresi pada kelompok tersebut akan tetapi dengan pemberian edukasi yang bertahap sebelum dan sesudah operasi dilakukan tingkat depresi semakin turun dan kembali ke normal (Huang, Sung, Wang, Wang, 2017). Status emosi responden yang lebih rendah ditunjukkan pada kelompok yang mendapatkan edukasi kesehatan melalui seni animasi film terintegrasi dan melibatkan seluruh tim kesehatan dibandingkan dengan kelompok yang mendapatkan pendidikan kesehatan pada umumnya (Shen et al., 2017)

\section{Simpulan dan saran}

Hasil ulasan yang menjadi perhatian penting adalah penggunaan media, durasi dalam memberikan edukasi kesehatan dan metode terintegrasi yang tepat saat melakukan edukasi karena sebagian besar pasien dengan operasi panggul adalah lansia. Kelompok usia lansia memiliki kerentanan terhadap perubahan fisik dan emosi yang sangat cepat. Penggunaan media yang kurang tepat akan memengaruhi hasil yang diharapkan dan akan memperlama proses pemulihan dan rehabilitasi. Kelima studi menunjukkan keefektifan edukasi pada pasien operasi panggul dan setiap studi memiliki hasil yang saling menguatkan satu dan lainnya. Edukasi kesehatan dilakukan sebelum dilakukan operasi dan akan berlangsung terus menerus sampai pasien mendapatkan derajat kesehatan yang makismal.

\section{Daftar Pustaka}

Bandura A (1977) Self-efficacy: toward aunifying theory of behavioral change. Psychological Review 84, 191-215

Barnsley, L., Barnsley, L., \& Page, R. (2015). Are Hip Precautions

Necessary Post Total Hip

Arthroplasty? A Systematic Review.

Geriatric Orthopaedic Surgery \&

Rehabilitation, 6(3), 230-235.

https://doi.org/10.1177/21514585155 84640

Birch, S., Stilling, M., Mechlenburg, I., \& Hansen, T. B. (2019). No effect of cognitive behavioral patient education for patients with pain catastrophizing before total knee arthroplasty: a randomized controlled trial. Acta orthopaedica, 1-6.

Centers for Disease Prevention and Control (CDC) (2019).

Characteristics of an Effective Health Education. Retrieved from Curriculumhttps://www.cdc.gov/heal thyschools/sher/characteristics/index. htm

Friedman, S. M., \& Mendelson, D. A. (2014). Epidemiology of fragility fractures. Clinics in Geriatric Medicine, 30(2), 175-181. https://doi.org/10.1016/j.cger.2014.0 1.001

Gurcayir, D., \& Karabulut, N. (2017). The Effects of the Training Provided to Patients who are scheduled for Hip Prosthesis Surgery on the Level of Postoperative Comfort and Daily Activities. International Journal of Caring Sciences, 10(1), 403-413. Retrieved from www.internationaljournalofcaringsci ences.org

Huang, T. T., Sung, C. C., Wang, W. S., \& Wang, B. H. (2017). The effects of the empowerment education program in older adults with total hip 
replacement surgery. Journal of

Advanced Nursing, 73(8), 1848-

1861.

https://doi.org/10.1111/jan.13267

Kennedy, D., Wainwright, A., Pereira, L.,

Robarts, S., Dickson, P., Christian,

J., \& Webster, F. (2017). A

qualitative study of patient education

needs for hip and knee

replacement. BMC musculoskeletal

disorders, 18(1), 413.

Luz Rodríguez Acelas, A., Monteiro

Mantovani, V., Cañon Montañez,

W., Engelman, B., Barragan da

Silva, M., \& de Abreu Almeida, M.

(2019). Evaluation of Acute Pain in

Patients Undergoing Total Hip

Arthroplasty: A Cohort Study.

International Journal of Nursing

Knowledge, 00(0), 1-5.

https://doi.org/10.1111/2047-

3095.12257

Marley, D., Sheikh, N., Taylor, J., \&

Kumar, A. (2018). Hip and knee arthroplasty. InnovAiT: Education

and Inspiration for General

Practice, 11(1), 20-27.

https://doi.org/10.1177/17557380177 39331

McDonald, S., Page, M. J., Beringer, K., Wasiak, J., \& Sprowson, A. (2014).

Preoperative education for hip or knee replacement. Cochrane Database of Systematic Reviews, (5).

Noor, Z. (2016). Buku Ajar Gangguan

Muskulpskeletal. (P. P. L. Aklia

Susila, Ed.) (II). Jakarta: Salemba Medika.

Reilly, M. O., Mohamed, K., Foy, D., \& Sheehan, E. (2018). Educational impact of joint replacement school for patients undergoing total hip and knee arthroplasty : a prospective cohort study.

Saul, D., Riekenberg, J., Ammon, J. C., Hoffmann, D. B., \& Sehmisch, S. (2019). Hip Fractures : Therapy, Timing , and Complication Spectrum, (July), 1-9. https://doi.org/10.1111/os.12524
Shen, W.-X., Wang, Y.-X., Ning, Y.-Y., Peng, J.-X., Wei, H.-Q., Duan, K., ... Yuan, C.-S. (2017). Influence of mobile education on joint function and quality of life in patients after total hip arthroplasty. Chinese Nursing Research, 4(2), 71-74. https://doi.org/10.1016/j.cnre.2017.0 2.002

van Rein, E. A. J., Sadiqi, S., Lansink, K. W. W., Lichtveld, R. A., van Vliet, R., Oner, F. C., ... van Heijl, M. (2018). The role of emergency medical service providers in the decision-making process of prehospital trauma triage. European Journal of Trauma and Emergency Surgery, $O(0), 0$. https://doi.org/10.1007/s00068-0181006-8

World Health Organization (WHO). (2018). Ageing and health. Retrieved from https://www.who.int/newsroom/fact-sheets/detail/ageing-andhealth

Yoon, R. S., Nellans, K. W., Geller, J. A., Kim, A. D., Jacobs, M. R., \& Macaulay, W. (2010). Patient education before hip or knee arthroplasty lowers length of stay. The Journal of arthroplasty, 25(4), 547-551.

Zhang, Y., Zhou, Z., Gao, J., Wang, D., Zhang, Q., Zhou, Z., ... \& Li, D. (2016). Health-related quality of life and its influencing factors for patients with hypertension: evidence from the urban and rural areas of Shaanxi Province, China. BMC health services research, 16(1), 27 
